\title{
Penerapan Prinsip-Prinsip Good Governance pada PT. BPR Kusemas Dana Mandiri
}

\author{
Ni Luh Putu Katrin Edelwis ${ }^{1}$ \\ I Gde Ary Wirajaya ${ }^{2}$ \\ 1,2Fakultas Ekonomi dan Bisnis Universitas Udayana, Indonesia \\ ${ }^{*}$ Correspondences : katrinedlws@gmail.com
}

\begin{abstract}
ABSTRAK
Sejak April 2020 PT. BPR Kusemas Dana Mandiri mengalami penurunan laba akibat dari pandemi COVID-19, namun PT. BPR Kusemas Dana Mandiri tetap bertahan menjalankan operasionalnya dengan baik dan tetap memberikan gaji penuh tanpa pemutusan hubungan kerja. Penelitian ini bertujuan mengetahui prinsip Good Governance (GG) yang diterapkan pada PT. BPR Kusemas Dana Mandiri menggunakan metode kualitatif. Analisis data yang digunakan adalah analisis deskriptif dengan pendekatan kualitatif. Hasil penelitian ini menyatakan prinsip transparansi, akuntabilitas, responsibilitas, independensi serta kesetaraan dan kewajaran telah diterapkan dengan baik oleh PT. BPR Kusemas Dana Mandiri. Implikasi pada penelitian ini diharapkan dapat menjadi pengingat dan bahan evaluasi mengenai pentingnya menerapkan prinsipprinsip Good Governance (GG) pada operasi perusahaan.
\end{abstract}

Kata Kunci: Good Governance; Akuntabilitas; Transparansi; Responsibilitas.

\section{Implementation of Good Governance Principles at PT. BPR Kusemas Dana Mandiri}

\section{ABSTRACT}

Since April 2020 PT. BPR Kusemas Dana Mandiri experienced a decline in profit due to the COVID-19 pandemic, but PT. BPR Kusemas Dana Mandiri continues to carry out its operations well and continues to provide full salaries without termination of employment. This study aims to determine the principles of Good Governance (GG) applied to PT. BPR Kusemas Dana Mandiri uses a qualitative method. The data analysis used is descriptive analysis with a qualitative approach. The results of this study state that the principles of transparency, accountability, responsibility, independence and equality and fairness have been implemented properly by PT. BPR Kusemas Mandiri Fund. The implications of this research are expected to be a reminder and evaluation material regarding the importance of applying the principles of Good Governance (GG) in the company's operations.

Keywords: Good Governance; Accountability; Transparency; Responsibility.

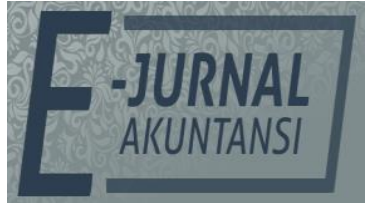

e-ISSN 2302-8556

Vol. 32 No. 1

Denpasar, Januari 2022

Hal. 30-42

DOI:

10.24843/EJA.2022.v32.i01.p03

PENGUTIPAN:

Edelwis, N. L. P. K. \&

Wirajaya, I. G. A. (2022).

Penerapan Prinsip-Prinsip

Good Governance pada PT.

BPR Kusemas Dana Mandiri.

E-Jurnal Akuntansi, 32(1),

$30-42$

RIWAYAT ARTIKEL:

Artikel Masuk:

24 Mei 2021

Artikel Diterima:

12 Januari 2022

Artikel dapat diakses : https://ojs.unud.ac.id/index.php/Akuntansi/index 


\section{PENDAHULUAN}

Lembaga keuangan di Indonesia dibagi menjadi dua yaitu, lembaga keuangan bank dan lembaga keuangan bukan bank. Lembaga keuangan bank (depository financial institution) adalah lembaga keuangan yang memberikan fasilitas dan jasa perbankan bagi masyarakat baik dalam penyimpanan, pembayaran, dan pemberian dana. Kelancaran usaha bank ditentukan oleh penerapan tata kelola pada lembaga perbankan itu sendiri, dalam prakteknya kegiatan bank dibedakan sesuai dengan jenis bank tersebut. Berdasarkan Pasal 5 (1) UU Perbankan, menurut jenisnya Bank terdiri dari Bank Umum dan Bank Perkreditan Rakyat (BPR) (Sawitri \& Ramantha, 2018).

Kebutuhan masyarakat di era globalisasi ini semakin tinggi sehingga masyarakat berusaha untuk mencari alat pemenuh kebutuhan, salah satunya melalui peminjaman dana. Mengingat tingginya kebutuhan masyarakat akan peminjaman dana, Bank Perkreditan Rakyat (BPR) menempati posisi yang penting dalam perekonomian (Hindistari, 2016). BPR memberikan pelayanan dalam sektor perbankan kepada masyarakat di daerah pedesaan dan pinggiran kota, termasuk kepada pengelola UMKM, sehingga BPR sangat diharapkan meningkatkan peran dan kontribusinya dalam pengembangan UMKM. Jika BPR tidak mampu menjalankan fungsinya dengan baik akan menyebabkan kesehatan BPR terganggu dan berujung pada likuidasi atau pembubaran (Suryaningsih \& Sudirman, 2020).

Dalam meningkatkan kepercayaan nasabah terhadap lembaga perbankan tentunya perlu ditunjukkan bahwa kinerja perusahaan atau lembaga perbankan tersebut baik. Kinerja perusahaan akan baik apabila perusahaan atau lembaga terkait mampu menerapkan sistem tata kelola perusaan dengan baik, efektif, dan efisien (Hasibuan \& Wirawati, 2020). Sistem tata kelola perusahaan atau yang lebih dikenal sebagai Good Governance (GG) merupakan sistem yang mengatur dan mengendalikan jalannya perusahaan yang nantinya mampu memberi nilai tambah atau value added bagi pemegang saham maupun investor (Wiantara \& Yadnyana, 2020). Perusahaan yang menerapkan GG dengan baik akan memberi keyakinan bagi investor bahwa mereka akan menerima return atas dana yang ditanamkan pada perusahaan maupun lembaga perbankan (Triadi, 2016). Apabila investor merasa yakin terhadap suatu perusahaan maka minat dalam menanamkan modal pada perusahaan tersebut akan semakin meningkat (Rahim, 2019). Hal tersebut menyebabkan, penerapan Good Governance (GG) merupakan hal yang sangat penting untuk diterapkan oleh semua jenis perusahaan maupun lembaga perbankan agar selalu menunjukkan kinerja yang baik pada suatu perusahaan (Sastra \& Erawati, 2017).

Pelaksanaan Good Governance (GG) sangat diperlukan untuk membangun kepercayaan masyarakat sebagai syarat mutlak bagi BPR untuk berkembang dengan baik dan sehat (Nawawi et al., 2017). Adanya tata kelola yang baik akan membantu meningkatkan kinerja perusahaan, sehingga tujuan perusahaan dapat tercapai. Tata kelola yang baik menunjukkan kecenderungan ke arah tanggung jawab perusahaan yang lebih besar dan perilaku bisnis dalam standar etika yang dapat diterima. Dalam menjalankan tata kelola perusahaan, tentunya didasari oleh prinsip-prinsip yang ada di dalam good governance (Nag, 2018). Prinsip prinsip Good Governance (GG) meliputi transparansi (transparency), akuntabilitas (accountability), responsibilitas (responsibility), independensi (independency), serta 
kewajaran dan kesetaraan (fairness) (Garbo \& Wulandari, 2018). Kelima prinsip tersebut diharapkan dapat menghasilkan keputusan yang lebih optimal untuk perusahaan (Yanti \& Wirajaya, 2020).

Prinsip GCG yang meliputi transparansi (transparency), akuntabilitas (accountability), responsibilitas (responsibility), independensi (independency), serta kewajaran dan kesetaraan (fairness) harus diimplementasikan dengan baik oleh sebuah lembaga perbankan agar kinerja keuangan dapat meningkat, sehingga tujuan perusahaan untuk mencapai tingkat profitabilitas yang diharapkan dapat tercapai (A. Putra \& Nuzula, 2017). Lembaga perbankan dalam menjalankan usaha tentunya menginginkan tingkat profitabilitas untuk keberlangsungan usahanya, namun apabila suatu perusahaan mengalami penurunan profitabilitas atau laba, hal tersebut mengindikasikan bahwa kinerja keuangan mengalami penurunan. Penurunan kinerja keuangan suatu lembaga perbankan salah satunya disebabkan oleh adanya penerapan prinsip-prinsip GG yang kurang baik (I. D. G. T. Putra \& Suardikha, 2020).

Sejak bulan April 2020 banyak BPR di Bali mengalami penurunan laba, salah satunya PT. BPR Kusemas Dana Mandiri yang berlokasi di Kecamatan Kuta, Kabupaten Badung. PT. BPR Kusemas Dana Mandiri merupakan salah satu badan usaha berbentuk Bank Perkreditan Rakyat (BPR) yang memiliki fungsi utama untuk menyimpan dan menyalurkan dana (kredit) kepada masyarakat. Penurunan laba ini terjadi akibat dampak dari pandemi COVID-19 yang mulai menyebar di Bali pada pertengahan bulan Maret 2020. Banyak nasabah yang hanya bisa membayar bunga kredit, disisi lain nasabah yang memiliki deposito menarik tabungannya. Hal ini merupakan permasalahan yang penting dalam dunia perbankan, begitu juga dengan PT. BPR Kusemas Dana Mandiri. Meski mengalami penurunan laba dikondisi pandemi saat ini, PT. BPR Kusemas Dana Mandiri tetap bertahan menjalankan operasionalnya dengan baik dan tidak lepas dari tanggung jawab untuk tetap memberikan gaji penuh kepada karyawannya serta tidak ada pemutusan hubungan kerja (PHK). Mengingat pentingnya prinsipprinsip GG yang harus diterapkan oleh suatu lembaga perbankan agar kinerja keuangan menjadi lebih baik, sehingga perlu dilakukan analisis terkait prinsip GG yang diterapkan oleh suatu lembaga perbankan. Berdasarkan pemaparan tersebut, maka kerangka konseptual penelitian dapat dirumuskan sebagai berikut.

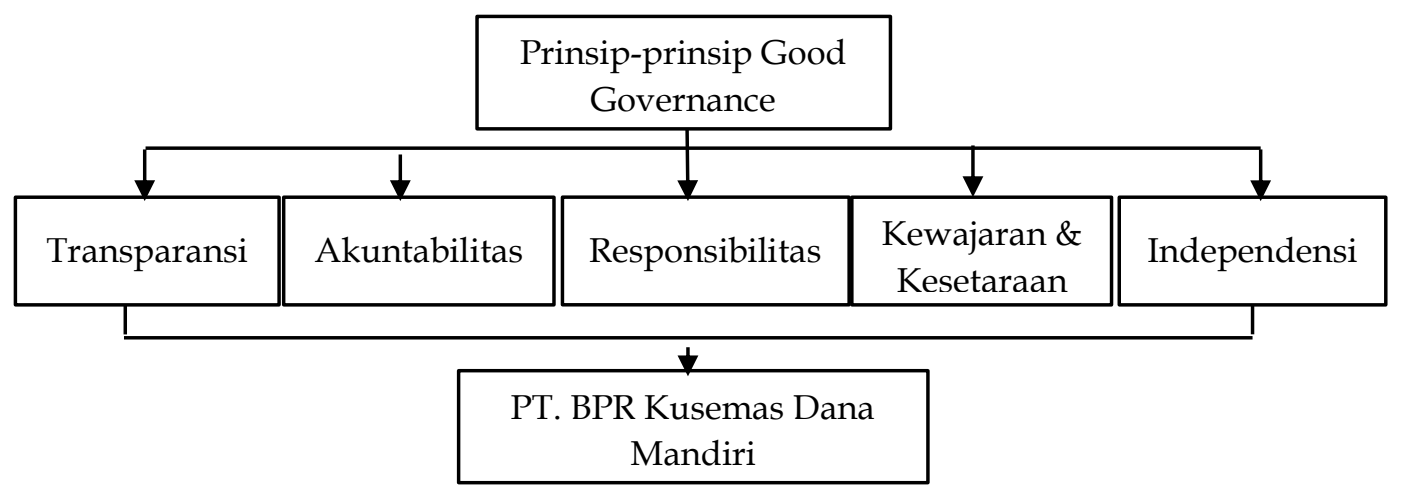

Sumber : Data Penelitian, 2021

Gambar 1. Kerangka Konseptual 
Teori yang mendasari penelitian ini adalah Theory of Reasoned Action (TRA) yang menghubungkan antara keyakinan (belief), sikap (attitude), kehendak (intention) dan perilaku (behavior). Teori ini disusun menggunakan asumsi dasar bahwa manusia berperilaku dengan cara yang sadar dan mempertimbangkan segala informasi yang tersedia. TRA lebih mengkonsentrasikan pada penyampaian tujuan tingkah laku secara eksplisit, bukan memprediksi perilaku apa yang akan dilakukan seseorang selanjutnya. TRA mengemukakan bahwa sebab terdekat (proximal cause) timbulnya perilaku bukan sikap, melainkan niat (intention) untuk melaksanakan perilaku itu (Mai, 2019)

Beberapa penelitian terdahulu yang menggunakan Theory of Reasoned Action dalam menjelaskan penerapan prinsip-prinsip Good Governance yaitu penelitian yang dilakukan oleh Otieno et al. (2016) dan Sukardika (2020). Good Governance (GG) merupakan suatu sistem tata kelola yang terdapat pada suatu perusahaan, dimana yang mengoperasikan sistem tersebut adalah manusia. Kesuksesan penerapan sistem tata kelola perusahaan ini bergantung pada komitmen dan integritas sumber daya manusia (SDM) yang mengoperasikan sistem tersebut (Sawmar \& Mohammed, 2021). Berbicara mengenai komitmen dan integritas, hal tersebut erat kaitannya dengan sikap dan perilaku. Ketika SDM memiliki niat untuk meningkatkan kinerja perusahaan, maka perilaku yang akan ditunjukkan adalah berkomitmen dalam melaksanakan segala kewajibannya, sehingga sistem tata kelola yang ada pada perusahaan dapat terlaksana sebagaimanamestinya. Hal ini akan berdampak pada penerapan prinsip-prinsip Good Governance (GG) yang dilaksanakan oleh seluruh anggota perusahaan (Pradnyaswari \& Putri, 2016).

Penelitian yang dilakukan oleh Otieno et al. (2016) menyatakan bahwa keyakinan individu mampu memengaruhi sikap individu dalam menjalankan sistem tata kelola yang baik. Ketika individu memiliki keyakinan bahwa dengan menerapkan prinsip Good Governancce (GG) dalam sistem tata kelola perusahaan dapat meningkatkan kinerja perusahaan, maka individu tersebut akan memiliki sikap yang berorientasi pada peningkatan kinerja perusahaan. Saat sikap seorang individu berorientasi pada peningkatan kinerja perusahaan, akan muncul kehendak melalui persepsi yang ditimbulkan atas sikap yang akan dilakukan oleh individu tersebut. Ketika individu memiliki persepsi bahwa dengan melaksanakan prinsip Good Governance (GG), tidak hanya akan meningkatkan kinerja perusahaan (Hutomo et al., 2020), namun juga dapat memberikan nilai tambah atas kinerja individualnya, sehingga akan muncul perilaku dari individu tersebut untuk berkomitmen dan berintegritas dalam menerapkankan prinsipprinsip Good Governance (GG) dalam sistem tata kelola perusahaan (Kushkowski et al., 2020). Dengan menerapkan prinsip-prinsip Good Governance (GG) dengan komitmen dan integritas akan mengurangi risiko adanya benturan kepentingan antar individu dalam perusahaan, adanya transparansi informasi, adanya pembagian hak-hak individu secara adil dan merata serta perilaku menaati peraturan yang ada, sehingga sistem tata kelola yang ada pada perusahaan dapat terlaksana dengan baik, yang nantinya akan berdampak pada peningkatan kinerja perusahaan, sehingga PT. BPR Kusemas Dana Mandiri dapat mencapai tujuan perusahaannya.

Permasalahan yang dihadapi PT. BPR Kusemas Dana Mandiri salah satunya yaitu penurunan laba akibat dampak dari pandemi COVID-19. Meski demikian, 
PT. BPR Kusemas Dana Mandiri tidak lepas dari tanggung jawab untuk tetap memberikan gaji penuh kepada karyawannya dan tidak ada pemutusan hubungan kerja (PHK) walaupun terjadi penurunan laba sejak April 2020.

Dengan penerapan teori reason action diharapkan permasalahanpermasalahan yang terjadi pada PT. BPR Kusemas Dana Mandiri dapat diminimalisir dengan memperhatikan sikap-sikap individu dalam organisasi sehingga visi, misi dan tujuan dapat tercapai. Selain itu dengan penerapan tata kelola yang baik, organisasi dapat sejalan dengan visi, misi dan tujuan organisasi

\section{METODE PENELITIAN}

Penelitian ini merupakan sebuah penelitian deskriptif dengan pendekatan kualitatif. Teknik pengumpulan data pada penelitian ini adalah dengan teknik triangulasi (gabungan), analisis data bersifat kualitatif dan hasil penelitian menekankan makna generalisasi. Hasil dari penelitian ini hanya mendeskripsikan atau mengkonstruksikan wawancara-wawancara mendalam terhadap subjek penelitian sehingga dapat memberikan gambaran yang jelas mengenai pemahaman bagaimana penerapan prinsip-prinsip Good Governance (GG) pada PT. BPR Kusemas Dana Mandiri.

Penelitian ini dilakukan di PT. BPR Kusemas Dana Mandiri yang berlokasi di Jl. Raya Tuban No. 56 Kuta, Badung. Lokasi penelitian tersebut dipilih karena dilihat dari kondisi pandemi saat ini PT. BPR Kusemas Dana Mandiri bisa bertahan menjalankan operasionalnya dengan baik. Subjek penelitian yang digunakan dalam penelitian ini adalah PE Kepatuhan, PE Audit Intern, Kepala Bagian Operasional dan Kepala Bagian Kredit PT. BPR Kusemas Dana Mandiri. Objek penelitian dalam penelitian ini adalah prinsip-prinsip Good Governance (GG) pada PT. BPR Kusemas Dana Mandiri.

Dalam penelitian ini data primer yang dimaksud adalah data yang diperoleh dari hasil observasi lapangan dan wawancara atau intervine dengan pihak-pihak yang berwenang dalam pengelolaan PT. BPR Kusemas Dana Mandiri. Peneliti akan langsung bertanya kepada narasumber yang berkompeten terkait hal-hal yang diteliti. Data sekunder yang terdapat dalam penelitian adalah data yang diperoleh dari instansi terkait, seperti sejarah berdirinya perusahaan, data struktur organisasi dan data-data lainnya yang relevan dengan penelitian ini. Metode pengumpulan data yang digunakan adalah melalui observasi, wawancara, dokumentasi dan studi pustaka.

\section{HASIL DAN PEMBAHASAN}

Wawancara yang dilakukan tanggal 7 Desember 2020 dengan Kepala Bagian Operasional. Berdasarkan hasil wawancara tersebut sudah dapat dipastikan bahwa PT. BPR Kusemas Dana Mandiri telah mengetahui apa itu Good Governance (GG) dan sudah menerapkan Good Governance (GG) sejak tanggal 1 April 2015. Walaupun terdapat beberapa kendala yang tidak terlalu berarti, PT. BPR Kusemas Dana Mandiri selalu memperhatikan kinerja karyawan yang nantinya dapat memengaruhi kinerja perusahaan. Lebih lanjut lagi, terkait penerapan tata kelola pada PT. BPR Kusemas Dana Mandiri tentunya tidak terlepas dari adanya penerapan prinsip-prinsip Good Governance (GG) yang harus diterapkan. Selain penerapan prinsip-prinsip Good Governance (GG) bagi pihak eksternal perusahaan, 
PT. BPR Kusemas Dana Mandiri juga menerapkan prinsip-prinsip GG bagi pihak internal perusahaan. Adapun prinsip-prinsip GG yang diterapkan oleh PT. Bank BPR Kusemas Dana Mandiri akan diuraikan sebagai berikut.

Transparansi dapat diartikan sebagai keterbukaan informasi, baik dalam proses pengambilan keputusan maupun dalam mengungkapkan informasi material dan relevan mengenai perusahaan (Nistor et al., 2019). PT. BPR Kusemas Dana Mandiri menerapkan prinsip tranparansi yaitu antara lain keterbukaan dalam hal rapat, keterbukaan informasi, keterbukaan prosedur yang berhubungan dengan prosedur pengambilan keputusan maupun prosedur penyusunan rencana, dan keterbukaan register mengenai informasi perusahaan. PT. BPR Kusemas Dana Mandiri melaporkan dan mempublikasikan laporan keuangan tahunan maupun triwulan ke website resmi yang mudah diakses oleh pihak-pihak yang berkepentingan. Selain itu, informasi mengenai produk-produk, tata cara pengaduan nasabah serta penyelesaian sengketa kepada nasabah pun juga sudah dipublikasikan dan dilaporkan sesuai dengan ketentuan yang diberikan oleh Otoritas Jasa Keuangan. Adanya keterbukaan organisasi dalam proses pengambilan keputusan dan mengemukakan informasi material yang relevan mengenai organisasi disampaikan pada saat rapat yang diadakan setiap bulan (monthly meeting).

Penerapan prinsip transparansi tidak hanya untuk pihak eksternal perusahaan saja, tetapi juga untuk pihak internal perusahaan. Dalam menjalankan operasional perusahaan, sistem tata kelola yang diterapkan harus berlandaskan dengan prinsip transparansi (Uzma, 2018). Menurut Theory of Reasoned Action yang menyatakan bahwa niat seseorang untuk melakukan suatu perilaku menentukan akan dilakukan atau tidak dilakukannya perilaku tersebut dimana asumsi yang mendasari teori ini menyatakan bahwa manusia berperilaku dengan cara yang sadar dan mempertimbangkan segala informasi yang tersedia. Hal ini menunjukkan bahwa, dalam menjalankan kegiatan operasional perusahaan diperlukan informasi yang tersedia dan terbuka agar setiap elemen-elemen yang ada di dalam sebuah perusahaan menunjukkan perilaku yang bertanggung jawab dalam menjalankan kewajibannya secara sadar. PT. BPR Kusemas Dana Mandiri sudah menerapkan prinsip Good Governance (GG) bagi pihak internal perusahaan yaitu prinsip transparansi dengan mengambil aspek keterbukaan informasi. Selain itu juga, melalui proses pengambilan keputusan dalam perusahaan dan evaluasi yang dilakukan untuk menerangkan bagaimana penerapan prinsip transparansi yang dilakukan di PT. BPR Kusemas Dana Mandiri.

Berdasarkan hasil wawancara, dapat diketahui bahwa PT. BPR Kusemas Dana Mandiri selaku lembaga perbankan sudah menerapkan salah satu prinsip Good Governance (GG), yaitu transparansi. PT. BPR Kusemas Dana Mandiri menerapkan prinsip tranparansi antara lain keterbukaan informasi, keterbukaan prosedur yang berhubungan dengan prosedur pengambilan keputusan maupun prosedur penyusunan rencana dan keterbukaan register mengenai informasi perusahaan. Seluruh laporan maupun informasi-informasi telah dipublikasikan melalui website resmi yang bisa diakses oleh seluruh pihak-pihak berkepentingan, baik mengenai produk-produk yang disediakan oleh bank, tata cara pengaduan nasabah, penyelesaian sengketa, laporan keuangan, maupun informasi lainnya. Selain itu juga, PT. BPR Kusemas Dana Mandiri juga telah melaporkan kepada 
Otoritas Jasa Keuangan terkait dengan laporan bulanan maupun triwulan dengan tata cara, jenis, serta cakupan yang telah ditentukan oleh OJK. Selain penerapan prinsip transparansi bagi pihak eksternal perusahaan, PT. BPR Kusemas Dana Mandiri juga menerapkan prinsip transparansi bagi pihak internal perusahaan seperti dalam hal keterbukaan informasi, pengambilan keputusan pada saat rapat, maupun dalam penentuan kebijakan yang akan diterapkan.

PT. BPR Kusemas Dana Mandiri telah menerapkan prinsip akuntabilitas dalam menjalankan usahanya. Salah satunya adalah setiap organ perusahaan pada bank sudah menjalankan fungsi dan job description secara jelas sesuai dengan sistem dan ketentuan yang berlaku pada bank. Selain itu, adanya tata cara pemberian kredit kepada para nasabah sudah sesuai dengan kebutuhan masyarakat sebagai nasabah. PT. BPR Kusemas Dana Mandiri juga dalam rangka meningkatkan akuntabilitas, telah memiliki auditor eksternal yang berkualitas dan independen melangsungkan praktik dengan efektif, sehingga laporan audit yang dihasilkan dapat relevan dan reliabel. Kejelasan fungsi dari masing-masing struktur, sistem dan pertanggungjawaban organ perusahaan sudah dapat dijelaskan, sehingga pengelolaan perusahaan dapat terlaksana secara efektif.

Penerapan prinsip akuntabilitas juga diperlukan untuk pihak internal perusahaan. Dalam menjalankan operasional perusahaan, sistem tata kelola yang diterapkan harus berlandaskan dengan prinsip akuntabilitas (Haliah \& Nirwana, 2019). Dalam menjalankan kegiatan operasional perusahaan diperlukan ketepatan fungsi antar elemen-elemen yang ada pada sebuah perusahaan, sehingga dengan adanya ketepatan fungsi ini sistem tata kelola yang diterapkan pada suatu perusahaan akan dapat terlaksana dengan baik sehingga kinerja perusahaan dapat ditingkatkan. PT. BPR Kusemas Dana Mandiri sudah menerapkan prinsip Good Governance (GG) bagi pihak internal perusahaan yaitu prinsip akuntabilitas yang dilihat dari kesesuaian antara pelaksanaan dengan standar prosedur pelaksanaan serta sanksi ataupun reward dengan kesalahan ataupun prestasi seseorang.

Berdasarkan hasil wawancara dengan Kepala Bagian Kredit, dapat disimpulkan bahwa PT. BPR Kusemas Dana Mandiri telah menerapkan prinsip Good Governance (GG), dalam hal ini yaitu akuntabilitas. Adanya kejelasan fungsi organ perusahaan yang ditunjukkan melalui adanya job description untuk masingmasing organ perusahaan, yang dijalankan sesuai dengan ketentuan yang berlaku. Sanksi tegas akan diberlakukan bagi organ perusahaan yang melakukan pelanggaran. Selain itu, terkait dengan laporan keuangan, agar tidak kehilangan kepercayaan para nasabah PT. BPR Kusemas Dana Mandiri telah memiliki auditor eksternal yang berkualitas, berkompeten dan tentunya independen, agar laporan audit atas kinerja bank pada suatu periode dapat relevan dan reliabel dan bertanggungjawab atas hasilnya. Segala informasi mengenai tata cara ketentuan pemberian kredit sudah diinformasikan secara efektif dan telah memperhitungkan tingkat suku bunga yang efektif atas pemberian kredit pada tiap tahunnya.

Tidak hanya dalam menghasilkan laporan keuangan yang relevan dan reliabel, ketepatan fungsi setiap elemen-elemen yang ada pada PT. BPR Kusemas Dana Mandiri juga menjadi perhatian karena dalam menghasilkan laporan keuangan yang relevan dan reliabel diperlukan ketepatan fungsi yang akuntabel. Karyawan PT. BPR Kusemas Dana Mandiri saling mengevaluasi pelaksanaan 
tugas, keterbukaan dan rasa saling percaya, karena hanya dalam iklim kerja yang terang-benderang dan suasana relasi antar karyawan yang diikat nilai saling memuliakan inilah anggota suatu komunitas/organisasi dapat mengolah informasi dengan optimal. Penerapan prinsip akuntabilitas yang dinilai dari keseharian karyawan PT. BPR Kusemas Dana Mandiri, yaitu dengan melakukan persembahyangan sehari-hari sebelum bekerja diharapkan agar karyawan dapat menumbuhkan aura positif dan menjaga keharmonisan di lingkungan kerja serta terhindar dari hal yang negatif termasuk rasa untuk melakukan kecurangan seperti korupsi atau saling menjatuhkan antar karyawan, karena seseorang yang berdoa sebelum melakukan pekerjaan mengerahkan semua daya dirinya untuk menunjukkan yang terbaik serta bertanggung jawab terhadap segala keputusan dan pekerjaan yang diambil.

PT. BPR Kusemas Dana Mandiri dalam menjalankan operasional perusahaan selalu berpedoman pada ketentuan-ketentuan yang berlaku, baik itu mengenai peraturan yang diterbitkan oleh Otoritas Jasa Keuangan, maupun ketentuan yang diberlakukan oleh Bank Indonesia selaku bank central. Dalam menjalankan operasi perusahaan, bank selalu mengutamakan kepentingan nasabah dengan selalu menjaga kerahasiaan data pribadi nasabah yang tidak boleh dijadikan informasi umum. Selain itu, sebagai bentuk pertanggungjawaban perusahaan, PT. BPR Kusemas Dana Mandiri selalu memperhatikan kesejahteraan para karyawannya. Penerapan prinsip responsibilitas pada suatu perusahaan tidak hanya mengenai bagaimana bentuk tanggung jawab suatu perusahaan kepada pihak-pihak berkepentingan, tetapi juga kepada lingkungan tempat perusahaan itu beroperasi maupun bagi masyarakat sekitar. Adanya keyakinan bahwa seseorang dalam melakukan kegiatan operasional suatu perusahaan akan memberikan dampak bagi lingkungan tempat bekerja maupun kepada masyarakat, sehingga perlu untuk diperhatikan. Hal ini akan menentukan sikap seseorang dalam berperilaku, apakah akan menjaga lingkungan bekerjanya ataupun mengabaikan dan hanya berfokus pada operasional perusahaan saja. PT. BPR Kusemas Dana Mandiri menerapkan prinsip responsibilitas tidak hanya kepada para nasabah, pemegang kepentingan, ataupun kepada karyawan saja, namun dalam kegiatan sehari-harinya PT. BPR Kusemas Dana Mandiri menerapkan pinsip responsibilitas ini dengan mengutamakan tanggung jawabnya kepada lingkungan tempat usahanya.

Berdasarkan hasil wawancara dengan PE Kepatuhan, dapat disimpulkan bahwa PT. BPR Kusemas Dana Mandiri sudah menerapkan prinsip Good Governance (GG), yaitu prinsip responsibilitas atau tanggungjawab. Prinsip ini diterapkan dengan menjalankan regulasi maupun peraturan serta ketentuan yang telah diberlakukan oleh OJK maupun Bank Indonesia. Hal tersebut dilihat dari melaksanakan tanggung jawab sosial dengan antara lain peduli terhadap masyarakat dan kelestarian lingkungan terutama di sekitar perusahaan, ditambah lagi dengan adanya pandemi COVID-19 ini PT. BPR Kusemas Dana Mandiri selalu menerapkan protokol kesehatan dan memerhatikan kebersihan lingkungan kerja agar dapat menciptakan lingkungan kerja yang nyaman bagi setiap elemen perusahaan maupun bagi nasabah.

Rasa tanggung jawab pihak bank kepada nasabahnya ditunjukkan salah satunya dengan menjaga informasi nasabah yang sifatnya rahasia. PT. BPR 
Kusemas Dana Mandiri juga selalu menunjukkan rasa tanggung jawabnya terhadap para karyawan dengan salah satunya memberikan tunjangan yang tentunya sesuai dengan ketentuan yang berlaku, sehingga kesejahteraan karyawan dapat selalu dijaga. Karyawan PT. BPR Kusemas Dana Mandiri selalu menunjukkan rasa tanggung jawabnya dengan menjalankan fungsi dan job description secara jelas sesuai dengan sistem dan ketentuan yang berlaku pada bank, serta pertanggungjawaban perusahaan yang berupa kepatuhan perusahaan terhadap hukum dan perundang-undangan yang berlaku, serta melaksanakan tanggung jawab terhadap nasabah sehingga dapat menjaga kesinambungan dalam jangka panjang.

PT. BPR Kusemas Dana Mandiri telah menerapkan independensi dalam operasi perusahaannya. Dengan menerapkan independensi, pengelolaan perusahaan akan mampu berjalan tanpa adanya benturan kepentingan antara pihak-pihak tertentu. Penerapan prinsip independensi juga diperlukan untuk pihak internal perusahaan. Dalam menjalankan operasional perusahaan, sistem tata kelola yang diterapkan harus berlandaskan dengan prinsip independensi. Dalam menjalankan kegiatan operasional perusahaan diperlukan sikap independen yang ditunjukkan oleh setiap karyawan. Dalam hal ini, karyawan dituntut untuk independen dalam menjalankan operasional perusahaan agar nantinya tidak akan terjadi benturan kepentingan yang dapat memengaruhi kinerja perusahaan. PT. BPR Kusemas Dana Mandiri sudah menerapkan prinsip independensi yang ditunjukkan melalui keindependenan setiap bidang-bidang yang ada pada perusahaan agar tidak adanya intervensi dari bidang satu dengan bidang yang lain yang nantinya dapat memengaruhi kinerja perusahaan.

Berdasarkan hasil wawancara dengan PE Kepatuhan, dapat diketahui bahwa PT. BPR Kusemas Dana Mandiri telah menerapkan prinsip Good Governance (GG), yaitu prinsip independensi. Setiap bagian yang berkaitan dengan kinerja perusahaan dijalankan secara independen agar tidak terjadi benturan kepentingan maupun intervensi dari berbagai pihak, seperti memberikan kebebasan dalam berpendapat, kebebasan menjalankan kegiatan operasional sehari-hari sesuai tugas yang diberikan sehingga kinerja perusahaan dapat berjalan dengan efektif dan kepercayaan para nasabah dapat dijaga. Perusahaan bertindak secara mandiri sesuai fungsi dan peran yang dimiliki masing-masing organ tanpa adanya tekanan. Perusahaan dikelola secara mandiri sehingga masing-masing organ tidak saling mendominasi dan tidak saling melempar tanggung jawab.

PT. BPR Kusemas Dana Mandiri telah melaksanakan prinsip kesetaraan dan kewajaran yang merupakan bagian dari penerapan Good Governance (GG). Segala informasi mengenai nasabah telah dipelihara secara memadai dan para nasabah diperlakukan secara hormat dengan memberikan pelayanan yang berkualitas. Berbagai kepentingan nasabah dan para stakeholder telah diperhatikan secara seksama, terutama bagi para stakeholder telah diperhatikan mengenai rasio bagi hasil. Adanya penghargaan maupun sanksi bagi karyawan yang berprestasi maupun yang melanggar ketentuan telah diberlakukan agar terjadinya keadilan pada tata kelola perusahaan yang dijalankan, sehingga kinerja perusahaan dapat berjalan dengan baik.

Theory of Reasoned Action menjelaskan tentang perilaku yang berubah berdasarkan hasil dari niat perilaku, dan niat perilaku dipengaruhi oleh norma 
sosial dan sikap individu terhadap perilaku tersebut. Dengan kata lain, dapat dikatakan bahwa sikap akan memengaruhi perilaku melalui suatu proses pengambilan keputusan yang cermat dan memiliki alasan. Dalam hal ini, penerapan prinsip kesetaraan dan kewajaran pada suatu perusahaan sangatlah penting. Dalam sebuah perusahaan, keputusan dan diambil akan sangat memengaruhi masa depan perusahaan, sehingga dalam proses pengambilan keputusan tersebut diperlukan kesetaraan bagi setiap elemen perusahaan untuk berpendapat. PT. BPR Kusemas Dana Mandiri sudah menerapkan prinsip kesetaraan dan kewajaran tidak hanya memerhatikan kepentingan stakeholder saja tetapi juga setiap elemen yang ada di perusahaan.

Berdasarkan hasil wawancara dengan PE Audit Intern, dapat disimpulkan bahwa PT. BPR Kusemas Dana Mandiri telah menerapkan prinsip Good Governance (GG), yaitu kesetaraan dan kewajaran. Dalam hal ini kesetaraan dan kewajaran yang dimaksud ditunjukkan dengan memberikan pelayanan yang berkualitas bagi seluruh nasabah maupun stakeholder. Selalu menjaga kepercayaan nasabah dan stakeholder adalah salah satu tujuan perusahaan untuk menjaga keberlangsungan hidup perusahaan. Kinerja yang baik dan kepercayaan para nasabah maupun stakeholder saling berhubungan sehingga selalu diperhatikan oleh PT. BPR Kusemas Dana Mandiri. Kesetaraaan dan kewajaran atas hak-hak maupun kepentingan stakeholder selalu diperhatikan oleh PT. BPR Kusemas Dana Mandiri, salah satunya adalah dengan memperhatikan rasio bagi hasil, hal ini mencerminkan seberapa baik kinerja yang dihasilkan oleh PT. BPR Kusemas Dana Mandiri dalam suatu periode dan ditujukan agar kepercayaan stakeholder terhadap keberlangsungan hidup perusahaan dapat terjaga. PT. BPR Kusemas Dana Mandiri selalu memberikan kesempatan kepada setiap karyawan untuk berpendapat dalam mengambil sebuah keputusan, serta memberikan kesempatan yang sama dalam pemberian hak cuti, penerimaan karyawan, berkarir dan melaksanakan tugasnya secara profesional tanpa membedakan suku, agama, ras, golongan, gender, dan kondisi fisik. PT. BPR Kusemas juga memberikan hak pada karyawan untuk memberi kritik dan saran terhadap kinerja atasan maupun sesama rekan kerja untuk meningkatkan kinerja perusahaan.

Penelitian ini secara teoretis dapat memberikan tambahan pengetahuan dan wawasan yang lebih luas mengenai bagimana prinsip-prinsip Good Governance (GG) yang diterapkan oleh suatu lembaga perbankan. Penelitian ini menemukan hasil mengenai bagaimana penerapan prinsip-prinsip GG pada PT. BPR Kusemas Dana Mandiri. Good Governance (GG) merupakan sistem tata kelola yang ada pada sebuah perusahaan, dimana sistem tata kelola ini penerapannya sangat diyakini memberikan kontribusi yang strategis dalam meningkatkan kesejahteraan rakyat, menciptakan iklim bisnis yang sehat, meningkatkan kemampuan daya saing, serta sangat efektif menghindari penyimpangan-penyimpangan. Implikasi teoretis pada penelitian ini juga memperkuat bukti Theory of Reasoned Action yang menyatakan bahwa niat seseorang untuk melakukan suatu perilaku menentukan akan dilakukan atau tidak dilakukannya perilaku tersebut adalah benar dengan PT. BPR Kusemas Dana Mandiri yang sudah menerapkan prinsip Good Governance (GG) bagi pihak internal perusahaan yaitu prinsip transparansi, akuntabilitas, responsibilitas, independensi serta kesetaraan dan kewajaran. Hasil penelitian ini menemukan bahwa penerapan prinsip-prinsip GG pada PT. BPR Kusemas Dana 
Mandiri sudah dilaksanakan dengan baik, sehingga disituasi pandemi COVID-19 saat ini PT. BPR Kusemas Dana Mandiri masih beroperasi dengan baik.

Penelitian ini dapat memberikan kontribusi positif bagi PT. BPR Kusemas Dana Mandiri baik secara langsung maupun tidak langsung. Dengan diketahuinya kinerja PT. BPR Kusemas Dana Mandiri yang sudah berjalan sesuai dengan prinsip-prinsip Good Governance (GG), maka akan mempermudah perusahaan dalam menjalankan program kerja dan memperbaiki kinerja yang dianggap kurang atau perlu ditingkatkan. Hasil penelitian ini dapat menjadi pengingat dan bahan evaluasi bagi PT. BPR Kusemas Dana Mandiri maupun lembaga perbankan lainnya mengenai pentingnya menerapkan prinsip-prinsip Good Governance (GG) pada operasional perusahaan. Hal ini dikarenakan, dengan menerapkan prinsip-prinsip GG dengan baik akan bermanfaat dalam mendukung perwujudan visi, misi dan strategi perusahaan. Selain itu, hasil penelitian ini dapat menjadi bahan pertimbangan dan referensi bagi peneliti selanjutnya yang tertarik untuk meneliti kajian yang sama di waktu yang akan datang.

\section{SIMPULAN}

Berdasarkan hasil penelitian dapat disimpulkan bahwa penerapan prinsip-prinsip Good Governance (GG) pada PT. BPR Kusemas Dana Mandiri secara garis besar telah diterapkan dengan baik. Penerapan prinsip transparansi ditunjukkan dengan adanya keterbukaan atas informasi terkait laporan keuangan maupun informasi lainnya sesuai dengan kebijakan yang ditetapkan oleh Otoritas Jasa Keuangan serta ketentuan lainnya. Penerapan prinsip akuntabilitas ditujukkan dengan adanya kejelasan dari masing-masing fungsi organ perusahaan serta pelaksanaan job description serta adanya auditor eksternal yang berkompeten. Selain itu, penerapan prinsip responsibilitas juga ditujukkan oleh adanya tanggung jawab perusahaan kepada nasabah maupun stakeholders serta pihak berkepentingan lainnya. Prinsip independensi ditunjukkan dengan adanya keterjaminan informasi nasabah serta adanya tenaga ahli yang independen dan tidak adanya intervensi dari pihak-pihak berkepentingan. Prinsip kesetaraan dan kewajaran ditunjukkan dengan adanya pelayanan yang berkualitas bagi seluruh nasabah serta selalu memperhatikan kepentingan stakeholder dengan baik.

Saran yang dapat diberikan yaitu PT. BPR Kusemas Dana Mandiri dalam menjalankan usahanya harus terus menjaga serta meningkatkan komitmennya dalam melaksanakan Good Governance (GG) sesuai dengan ketentuan dan kebijakan yang diberikan oleh Otoritas Jasa Keuangan maupun regulasi lainnya. Independensi dari pihak-pihak yang melakukan assessment pelaksanaan GG diharapkan untuk ditingkatkan, tidak hanya bagi internal perusahaan tetapi juga bagi eksternal. Pada penelitian selanjutnya disarankan untuk melakukan penelitian tidak hanya pada lembaga perbankan namun pada perusahaanperusahaan lainnya mengingat pentingnya Good Governance (GG) untuk diterapkan pada suatu perusahaan agar memberikan suatu pandangan yang lebih luas dan dalam mencegah kendala yang sama. Bagi peneliti selanjutnya disarankan untuk mengelola dan memastikan waktu saat melakukan wawancara agar saat informan memberikan informasi bisa dilakukan secara efektif. Adapun terkait pandemi COVID-19 yang menyebabkan peneliti terbatas dalam mendapatkan informan maka disarankan pada penelitian selanjutnya tidak hanya 
dari internal perusahaan tetapi juga dari eksternal agar mendapatkan hasil yang lebih valid dan konfirmasi yang tepat bahwa Good Governance (GG) yang dilakukan sebuah perusahaan sudah dijalankan dengan baik.

\section{REFERENSI}

Garbo, A., \& Wulandari, D. A. (2018). The implementation of good corporate governance in the Aerofood ACS Company of Yogyakarta. Journal of Islamic Lariba, 4(1), 47-56.

Haliah, \& Nirwana. (2019). The development of good governance model for performance improvement. International Journal of Excellence in Government, 1(1), 21-36. https:/ / doi.org/https:// doi.org/10.1108/IJEG-09-2018-0004

Hasibuan, M. E., \& Wirawati, N. G. P. (2020). The Effect of Financial Performance , Good Corporate Governance, Corporate Social Responsibility on Company Value ( Empirical Study on Food and Beverage Companies Listed on the Indonesia Stock Exchange 2017-2019 ). American Journal of Humanities and Social Sciences Research (AJHSSR), 5(1), 391-397.

Hindistari, R., \& Putri, A. D. (2016). Pengaruh Penerapan Prinsip-Prinsip Good Corporate Governance Pada Kinerja Bank Perkreditan Rakyat Kabupaten Gianyar. E-Jurnal Akuntansi, 16(1), 101-128.

Hutomo, A., Marditama, T., Limakrisna, N., Sentosa, I., Lee, J., \& Yew, K. (2020). Green Human Resource Management, Customer Environmental Collaboration and the Enablers of Green Employee Empowerment: Enhanching an Environmental Performance. DIJEFA, 1(2), 358-372. https://doi.org/10.38035/DIJEFA

Kushkowski, J. D., Shrader, C. ., Anderson, M. H., \& White, R. . (2020). Information flows and topic modeling in corporate governance. Journal of Documentation, 76(6), 1. https://doi.org/https://doi.org/10.1108/JD-10-2019-0207

Nag, N. S. (2018). Government, Governance and Good Governance. Indian Journal of Public Administration, 64(1), 122-130. https://doi.org/10.1177/0019556117735448

Nawawi, S., Herawati, N. T., \& Prayudi, M. A. (2017). Analisa Penerapan PrinsipPrinsip Good Corporate Governance Dalam Proedur Pemberian Kredit. EJurnal Akuntansi, 8(2), 1-10.

Nistor, C. S., Stefanescu, C. A., Oprisor, T., \& Crisan, A. . (2019). Approaching public sector transparency through an integrated reporting benchmark. Journal of Financial Reporting and Accounting, 17(2), 249-270. https://doi.org/https://doi.org/10.1108/JFRA-06-2017-0048

Otieno, O. C., Liyala, S., Odongo, B. C., \& Abeka, S. (2016). Theory of Reasoned Action as an Underpinning to Technological Innovation Adoption Studies. World Journal of Computer Application and Technology, 4(1), 1-7. https://doi.org/10.13189/wjcat.2016.040101

Pradnyaswari, L., \& Putri, I. G. A. M. . A. D. (2016). Pengaruh Prinsip-Prinsip Good Corporate Governance Pada Kinerja Keuangan Koperasi Di Kabupaten Klungkung. E-Jurnal Akuntansi, 14(2), 1064-1091.

Putra, A., \& Nuzula, N. (2017). PENGARUH CORPORATE GOVERNANCE TERHADAP PROFITABILITAS (Studi Pada Perusahaan Perbankan yang Terdaftar di Bursa Efek Indonesia Periode 2013-2015). Jurnal Administrasi 
Bisnis S1 Universitas Brawijaya, 47(1), 103-112.

Putra, I. D. G. T., \& Suardikha, I. M. S. (2020). The Effect of the Implementation of Good Governance and Accounting Information Systems on the Performance of Village Credit Institutions ( LPD ). American Journal of Humanities and Social Sciences Research (AJHSSR), 4(8), 225-231.

Rahim, A. (2019). Governance and Good Governance-A Conceptual Perspective. Journal of Public Administration and Governance, 9(3), 133. https://doi.org/10.5296/jpag.v9i3.15417

Sastra, I. M. B., \& Erawati, N. M. A. (2017). Pengaruh Penerapan Prinsip-prinsip Good Corporate Governance dan Budaya Tri Hita Karana pada Kinerja Keuangan. E-Jurnal Akuntansi Universitas Udayana, 19(1), 421-451.

Sawitri, P. P., \& Ramantha, I. W. (2018). Pengaruh Penerapan Prinsip-prinsip Good Corporate Governance Pada Kinerja Bank Perkreditan Rakyat di Kota $\begin{array}{llll}\text { Denpasar. E-Jurnal 23(1), } & 1093 .\end{array}$ https:// doi.org/https:// doi.org/10.24843/ eja.2018.v23.i02.p11

Sawmar, A. A., \& Mohammed, M. . (2021). Enhancing zakat compliance through good governance: a conceptual framework. ISRA International Journal of Islamic Finance, 1(1), 1. https://doi.org/https://doi.org/10.1108/IJIF-102018-0116

Sukardika, I. W., Wahyu Purna Anggara, I. W. G., \& Andika Pradnyana Wistawan, I. M. (2020). Pengaruh Penerapan Prinsip-Prinsip Good Corporate Governance pada Kinerja Bank Perkreditan Rakyat di Kabupaten Badung. EJurnal Akuntansi, 30(8), 2025. https://doi.org/10.24843/eja.2020.v30.i08.p10

Suryaningsih, N. P. R., \& Sudirman, M. S. N. (2020). The influence of credit risk, liquidity risk, and operational risk on profitability in rural banks in Bali Province. American Journal of Humanities and Social Sciences Research, 4(3), 258265.

Mai, T. T. N. (2019). An investigation into the relationship between materialism and green purchase behavior in Vietnam and Taiwan. Journal of Economics and Development, 21(2), 247-258. https://doi.org/https://doi.org/10.1108/JED10-2019-0044

Triadi, A. A. L. (2016). Pengaruh Pengendalian Intern dan Penerapan PrinsipPrinsip Good Corporate Governance Terhadap Kinerja Manajerial (Studi Pada PT BRI Persero Tbk. Cabang Denpasar). E-Jurnal Akuntansi Universitas Udayana, 16(2), 895-920.

Uzma, S. (2018). Corporate governance practices: global convergence and Indian perspective. Qualitative Research in Financial Markets, 10(3), 285-308. https://doi.org/https://doi.org/10.1108/QRFM-12-2016-0049

Wiantara, I. W. W., \& Yadnyana, I. K. (2020). The Influence of Application of Good Government Governance Principles and Tri Hita Karana Culture on Regional Government Performance. American Journal of Humanities and Social Science Research (AJHHSR), 4(8), 74-82.

Yanti, L. A. K., \& Ary Wirajaya, I. G. (2020). Pengaruh Prinsip-Prinsip Good Governance pada Kinerja Keuangan LPD di Kabupaten Karangasem. E-Jurnal Akuntansi, 30(3), 713-724. https://doi.org/https://doi.org/10.24843/ eja.2020.v30.i03.p13 